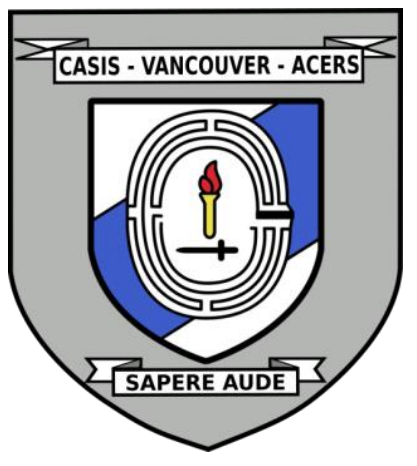

\title{
THE MORALITY OF SECURITY
}

Date: November 26, 2021

Disclaimer: This briefing note contains the encapsulation of views presented by the speaker and does not exclusively represent the views of the Canadian Association for Security and Intelligence Studies.

\section{KEY EVENTS}

On November 26, 2021, Dr. Rita Floyd, Associate Professor at the University of Birmingham, presented on The Morality of Security at the 2021 CASIS West Coast Security Conference. Dr. Floyd's presentation focused on securitization and its emergence within politics, with some primary concepts centering around security threats being politically and socially constructed and the criteria for when securitization is morally justifiable. Dr. Floyd's presentation was followed by a question-and-answer period directed at a group of panelists allowing the audience and CASIS Vancouver executives to directly engage with the content of each speaker's presentation.

\section{NATURE OF DISCUSSION}

\section{Presentation}

The primary focus of Dr. Floyd's presentation was the importance of just securitization, as well as emergency politics as a recurring phenomenon and the nature of securitization for different types of threats. Dr. Floyd also discussed Just Securitization Theory and its principles, which derive from her book: The Morality of Security: A Theory of Just Securitization.

\section{Question Period}

Discussion during the question-and-answer period focused on the ethical considerations of just securitization theory that the upcoming generations of military officers need to properly acquaint themselves with. The public's perceptions when it comes to morally just decision-making by practitioners was also discussed. 


\section{BACKGROUND}

\section{Presentation}

Dr. Floyd began by arguing that successful securitization includes the adaptation of extraordinary emergency measures, thus securitization is often associated with emergency politics. She stated that there will always be emergency politics, notably, not all threats that require or permit securitization are instigated by aggressors. For example, the threat of climate emergency, migration, or COVID19 are not agent-intended but merely agent-caused. Moreover, although securitization involves extraordinary measures, the nature of securitization is threat dependent; an emergency response to COVID-19 looks different to a securitizing response to terrorism.

In recent years, the public and government have bettered their understanding of what securitization is, specifically in the context of COVID-19, which has prompted and continues to prompt national lockdowns. In addition, securitization may sometimes entail an increase in police powers or greater enforcement of emergency legislation as it has in some cases been observed with the pandemic.

Dr. Floyd noted that securitization often also means an increase in surveillance, which has been normalized in today's world through closed-circuit television and facial recognition technology. This shows that securitization tends to conflict with personal liberty. As such, there is always a tradeoff between security and liberty, which is exemplified by the COVID-19 pandemic as there has been an increase in surveillance and a reduction in privacy. As a result, Dr. Floyd noted, there are serious implications for practitioners when it comes to emergency politics: it is easy to make mistakes and actions can be deemed excessive. For example, since the pandemic began, the United Kingdom's government has been criticized as undemocratic. In many countries there have been protests regarding the unethical and undemocratic actions taken by governments trying to impose new lockdowns or de facto mandatory vaccinations.

If one looks at the critical security studies literature to see when securitization is morally permissible, one finds little. Most scholars favor desecuritization, precisely because securitization has negative consequences. The best course of action, according to these studies, is to not securitize and follow normal politics. The problem with this logic is that it only works if the existence of real threats is ignored. However, practitioners have an obligation to the people to address threats in the best way that they can, and when threats are real, this may mean

The Journal of Intelligence, Conflict, and Warfare Volume 4, Issue 3 
securitization. An example of a failure in securitization is the case of Jair Bolsonaro. His decision not to securitize the COVID pandemic may cost him his political career in Brazil, and he might even be criminally charged. Protests in Brazil have the opposite message seen in other parts of the world as people are asking for securitization and vaccinations.

Dr. Floyd stated that in the scholarly community there needs to be more coherent thinking surrounding how and when to use emergency politics. In this context, Dr Floyd introduced her own Just Securitization Theory. This theory develops a set of principles that designate when securitization is morally permissible. This theory is broken down into three groups of principles:

1. Just initiation of securitization

a. There should be an objective existential threat to referent object of security.

b. The only eligible referent objects for just securitization are ones that meet basic human needs.

c. The securitizing actor must be sincere in their intention.

d. Securitization cannot cause more harm than it seeks to prevent.

e. Securitization must be expected to have a greater chance at achieving a just cause than less harmful alternatives.

2. Just conduct of securitization

a. Security measures must be targeted to the threat.

b. Among the choice of measures, where possible, the least harmful one must be chosen.

c. The executors of securitization are constrained in their actions by the rights of inter alia suspects and threateners.

3. Just termination of securitization

a. Desecuritization must occur when real threats have been neutralized

b. Desecuritization ought to involve rhetorical desecuritizing moves and the unmaking of emergency measures

c. Desecuritization ought to involve context-specific restorative measures to ensure lasting peace/security.

Latterly Dr Floyd has been working on the moral obligation to securitize, which she refers to as mandatory securitization.

Dr. Floyd concluded her presentation by noting that the three aims of Just Securitization Theory in emergency politics are to enable scholars and

The Journal of Intelligence, Conflict, and Warfare

Volume 4, Issue 3 
practitioners to evaluate the ethics of securitizations' past and present, to empower the general public to hold practitioners accountable for how they securitize or desecuritize, and to equip the practitioners to make informed judgements on what they ought to do in relevant situations.

\section{Question Period}

During the question-and-answer period Dr. Floyd pointed out that as technology continues to progress, the ways in which ethical thinking can be applied to practical concerns become ever more important. The application of technology in emergency politics is increasingly developing into an issue that the younger generations are becoming aware of and actively criticizing. These generations should not be afraid to question the ethics of particular policies and security measures. This applies especially to new generations of security practitioners.

With regards to decision-making of practitioners and the value of morally just decisions, Dr. Floyd noted that even if practitioners do not care about securitizing threats on moral grounds, they may still be concerned with legitimacy and whether they are perceived as doing the right thing. Often, the hesitancy and resistance against securitization comes from the public's lack of understanding on why it needs to happen and a perception that some measures are unethical; some examples of this include facial recognition technology and COVID-19 securitization measures.

\section{KEY POINTS OF DISCUSSION}

\section{Presentation}

- Just conduct of securitization focuses on the need for security measures to have a threat target and to prioritize the least harmful measure.

- Practitioners need to be equipped properly to make informed judgements on how to evaluate threats and pick out the best ethical measures.

- Although securitization has inescapable negative consequences, desecuritization is not always a good alternative as it rests on the view that it is not important to theorize or consider real threats.

- Practitioners have an obligation to address threats in the best way they can, which may mean securitizing.

- There needs to be more coherent thinking surrounding how and when to use emergency politics and when securitization is morally permissible.

The Journal of Intelligence, Conflict, and Warfare 


\section{Question Period}

- New generations must continue to question policies based on their ethical standings rather than following tradition.

- Oftentimes, the hesitancy and rejection of securitization comes from a lack of knowledge on why these measures need to be taken, with COVID-19 being the most recent example.

- Practitioners and policymakers' legitimacy depends on the general public's perception of their actions and behaviors, thus putting morally just decisions in the forefront of decision-making.

\section{@ $\odot \Theta$} Commercial-NoDerivatives 4.0 International License.

(C) (RITA FLOYD, 2022)

Published by the Journal of Intelligence, Conflict, and Warfare and Simon Fraser University

Available from: https://jicw.org/

The Journal of Intelligence, Conflict, and Warfare

Volume 4, Issue 3 